\title{
Financial Decline of Pakistan Railways and Prospective Turnaround
}

\author{
Kashif Farooq Ch.
}

\begin{abstract}
We have studied the financial performance of Pakistan Railways and found that the financial indicator (net earnings ratio) of Pakistan Railways is consistently decreasing over the years, causing severe financial and operational crises. The implication of our study indicates that the '3Rs' Strategy (retrenchment, repositioning and reorganizing) should be put into practice and furthermore, favorable changes in environmental factors can also contribute towards organizational turnaround. This study would help the Government of Pakistan to think and plan more clearly about turnaround strategies that could improve the performance and growth of Pakistan Railways.
\end{abstract}

Keywords : Pakistan Railway, Financial highlights, 3R's Strategy

\section{Introduction}

Pakistan Railways (PR) was established on May 13, 1861 with some other name. This organization is under direct control of Federal Government of Pakistan. At the time of its existence, Karachi and Kotri stations, having distance of $169 \mathrm{KMs}$ were connected through a Railway line. Historically it was being named as North Western Railways having route of $11,088 \mathrm{KMs}$. At the time of partition the routs of 3,043 KMs were shifted to India and rest of the route of $8,045 \mathrm{KMs}$ became part of the Pakistan. Later on the name of this organization was changed to Pakistan Western Railway in 1961. And finally, in 1974 it was named as Pakistan Railways.

The Railway board has been given command for general planning, controlling, organizing and administrating the management of the matter related to Pakistan Railways. The Railway board consists of six (6) members including a chairman. Three out of six members are from private sector. The chairman of the board is nominated from the Secretary to the Government of Pakistan, Ministry of Railways. The Chief Executive Officer is appointed

\footnotetext{
Corresponding author: Muhammad Javed Anwar. Central Superior Services of Pakistan, Railways Group

E-mail : allah4us@hotmail.com

(c) The Korean Society for Railway 2013

http://dx.doi.org/10.7782/IJR.2013.6.4.131
}

from the post of General Manager, Railways who is the head of the organization's structure. Four additional General Managers provide assistance to the Head General Manager.

In transport segment, the Railway of Pakistan has not retained its strong place to help win its customers. The market share of this organization has downwards trend during the course of time. It can be well judged from an example that in 1970's the volume of passengers, that were carried annually by Pakistan Railways, was 145 million passengers approximately which with the passage of time decreased to 59 million passengers only in 19921993. Table 5 shows the summary of passenger earnings ratio of Pakistan Railways. Similarly another example of its decreasing market share is that only $11 \%$ of petroleum goods and $2 \%$ of the overall containers are being carried by the PR. In contrast, the more efficiently and effectively controlled Railways have substantial potential for growth.

Pakistan Railways was a self- sufficient entity till 1970's. It was being run by the Railway Board which consisted of four independent members including Member Traffic, Member Mechanical, Member Civil and Member Finance. One of the members was nominated from the ministry of finance and the rest of three members were appointed from senior employees of Railway having vast experience and specialization in their respective work. The chairman of the board was appointed out of these three specialized members with the approval of the Govern- 
ment of Pakistan. Later on the fifth member was also appointed as the Vice Chairman of the Board to control and administer day to day operations and action plan.

The Government appointed a new officer as the Chairman of the Board in 1990 from the officers of the Civil Services of Pakistan. Since the appointment of the new Chairman, the performance of the Pakistan Railways has downward trend continuously in financial and operational segment. This can be well understood through the financial indicators of Pakistan Railway as mentioned in the Tables 1 and 2 .

Currently the budget of Rs 13.63 billion has been allocated by the federal government for Pakistan Railways but still this entity is facing financial crises and also operational crises in the form of lack of good quality locomotives. The carriage of goods was the major segment of Pakistan Railways contributing 54\% of the overall revenue of PR. But recently it has decreased to $32 \%$. Figures shown in Table 3 depict the decreasing trend of business of carriage of goods. At present time this organization is being controlled and run by an inefficient non-operational board that merely exists on working papers. There are no strategic directions of this board to achieve key goals and objectives of the organization. The factory of carriage situated in Islamabad used to export wagons and coaches to different South Asian countries like Sri Lanka and Bangladesh even after meet its own internal requisites. But presently this factory has been virtually shut down. Moreover this has caused the reason to import such wagons and coaches which PR was exporting earlier.

PR is importing high capacity wagons from China despite of availability of production facilities of such wagons in Moghalpura. The axle load of these imported wagons is very limited which is the biggest disadvantage. In Past GE, Hitachi and other companies used to provide us locomotives. Although such locomotives provided by these reputed companies had different axle load but they were quite compatible with the Railway tracks.

In the era of General Pervaiz Musharaf, three candidates were appointed at three different positions that had no formal expertise and specialization in Railway. General Javed Ashraf as Railway Minister, General Saeed as the Chairman and General Hamid Butt as General Manager of Manufacturing and Services.

On 21 November 2010, Daily Times reported that Pakistan Railways unable to achieve desired financial results. The administration of PR had not been able to attain the stipulated financial results through best utilization of resources for achieving the targeted outcomes to take care of its revenue receipts by achieving the targets and curtailing revenue expenditure by keeping the same within allot- ted funds. It was declared by the Auditor General Pakistan's office in its latest audit observation for the financial year 2009 - 2010.

The topic financial decline of Pakistan Railways and prospective turnaround has been selected to highlight the major reasons and impact of the financial crisis of Pakistan Railways and to suggest ways to improve the efficiency and effectiveness in the financial performance of Pakistan Railways.

The research on this topic is important for various reasons because it has been internationally recognized that the compatible strategies are required for the turnaround of public services. Boyne (2010) stated 3Rs strategy for the public service turnaround : Retrenchment, repositioning and reorganization.

Different studies on public sector turnaround have been conducted largely on the Power Distribution, Oil and Gas Distribution, Education, Law enforcement Agencies etc but study on Pakistan Railways, despite of being largest public sector organization has not been subjected to research. This study has been conducted to bridge this gap.

This study has been organised in 6 sections. Section 1 is the introduction. Pakistan Railway's performance overview is given in section 2. Literature review is in section 3. Data collection and methodology is in section 4. Analysis and results are given in section 5 and finally conclusion is given in section 6 .

\section{Overview of the Financial Performance of the Pakistan Railways}

The financial performance decline of the PR can be gauged from the key financial performance indicators shown in Table 1. The Auditor General of Pakistan (AGP), the State Bank of Pakistan (SBP), as well as the World Bank transport division, among others, use these indicators for financial performance assessment of the Railways (World Bank).

The financial performance indicators of PR as given in Table I, show consistent decline upto 2009. The capital of PR has been increased from Rs. 29,524,219 to Rs. 46,646,332 from the year 2004 - 2008 respectively. Which indicate the substantial investment of GOP in PR. Although the Gross Earnings of Pakistan Railways has increased from last 5 years but due to heavy operating expenses the $\mathrm{PR}$ is sustaining substantial net losses over the period.

Pakistan Railways (PR) administration had not been able to attain the stipulated financial results through best utilization of resources for achieving the targeted outcome to take care of its revenue receipts by achieving the targets and curtailing revenue expenditure by keeping the same 
within allotted funds.

It was declared by the Auditor General Pakistan's office in its latest audit observation for financial year 2009 2010. AGP revealed that there has been abnormal increase in the overdraft (OD) coupled with no serious efforts undertaken by PR except that compulsory /obligatory payments of GPF (gross provident fund), salaries etc. and other committed liabilities are being deferred to improve cash management which is highly irrational and illegal method of doing this.

Document stated that as per regulations of State Bank of Pakistan (SBP), PR is required to pay interest on OD up to Rs 4 billion at the rate charged to the treasury bills and for the over and above amount at commercial rates.OD of PR has touched the figure of Rs.35.198 billion including Ways and Means Advance on June 30, 2009 as against Rs.15.152 billion in financial year 2004 - 2005, that is $132 \%$ increase over a period of 5 years.

The analysis of financial statements of PR for the last five years conducted by audit revealed that dependence of Pakistan Railways on OD, provided by SBP, has substantially increased. In FY 2008 - 2009, exceptionally high increase of Rs 9.856 billion in OD was observed; which is $39 \%$ of total OD of last five years comes Rs 22.347 billion whereas the average OD of the five years proceeding to that (1999 -2000 - $2003-2004)$ is Rs 17.905 million. The comparison of average rates of booth these periods showed increase of Rs 4.442 billion, which is alarming.

Furthermore, PR is paying persistently huge amount of interest on OD due to lack of planning and management of funds/operation. During FY 2004 - 2005, PR had paid Rs 49.384 million on account of interest on OD; this figure jumped to Rs 396.855 million having impact of $704 \%$ increase during FY 2008 - 2009. Similarly the scrutiny of record managed by AGP officials regarding "Procurement/ manufacturing of 75 D.E locomotives" disclosed that Pakistan Railways failed to assess the financial implications and decided injudiciously to purchase new locomotives despite strong financial crunch in most profitable institution of the country.

Audit revealed that injudicious decisions taken by Federal Railway Minister Ghulam Ahmed Bilour as a part of present regime regarding the purchase of 75 new locomotive engines, Pakistan Railways faced the loss of Rs 5.581 billion (approximately). As per PC-1 total cost of one new 75 D.E Loco engine procured from China was Rs. 12.700 billion excluding the amount of interest over the contact as Rs.5.608 billion (approximately), While PR could save the amount of Rs 5.581 billion if the right decisions were taken as it spent $40.64 \%$ less amount on the rehabilitation of old locomotives engine.

\section{Literature Review}

Turnaround has been defined as "performance decline followed by performance improvement" (Schendel et al., 1976; Robbins and Pearce, 1992). Brandes and Brege (1993) define it as "a process that takes a company from a situation of poor performance to a situation of good sustained performance". Beeri (2006) states "turnaround management strategies have majorly been deployed on private sector organization but the public sectors have been ignored. However these strategies have now been implemented in public sectors in recent time". Retrenchment, repositioning and reorganisation are the three fundamental strategies for organizational turnaround (Hoffman, 1989; Pearce and Robbins, 1993). Retrenchment is composed of several sub-strategies for example refraining from tricky markets, cutting down non-profitable goods segment, disposing off assets, downscale employment opportunities and availing third party facilities (outsourcing). There are several researches and studies that complement these ways of actions. Robbins and Pearce (1992) argued that 'disposing off assets and reduction in overheads can provide bases for revival of businesses. Hoffman (1989) argued that cost controlling is the vital factor for organizational turnaround. Many of the modern studies by Bruton (2003); Dawley (2002) and Morrow (2004) have concluded that there is a positive relationship between retrenchment and organizational turnaround.

As per above discussion we conceive as mentioned below:

The basic idea behind retrenchment approach is to reduce cost and recoup efficiencies in the entity. On the other hand the approach of repositioning is related to boost up the revenue. Boyne and Meier (2005) stated that the vital part of repositioning approach is to make revenues. It concentrates on enlargement and improvement of business. Boyne (2006) argued that this approach is composed of different sub-strategies including approaching fresh marketplace, creating new basis for revenue generation, production of radically changed goods, and change in the mission and reflection of the entity. This approach also focuses on changing the view points of business partners and stake holders (Arogyaswamy, 1995). Similarly in the case also, the positive relationship has been found between repositioning and organizational turnaround. Re-organization is the third strategy for organizational turnaround. As argued by Boyne (2006), this approach is also composed of several sub-strategies including improvement in developing business plans and strategies, the level of delegation of authorities, human resource management techniques and cultural and ethical values of the organization'. This approach also highlights the rotation and change in leader- 
ship and executive personnel. The literature on turnaround has concentrated on positive impact on organizational revival thorough the expertise of the leaders and senior executive personnel. A competitive human resource strategy may lead to the improvement of financial performance of the organization. Current researches by Hitt et al. (2001) and Skaggs and Youndt (2004) also argue in the favour of this approach. On the basis of above discussion we develop the following proposition;

A business is conducted around four external sources. These may include political and legal, economical, social and technical environment. These may be grouped as Environmental factors. Several turnaround studies have not discussed the impact of environmental factor on the turnaround of the organization. Positive environmental have positive impact on the revival of the organization. So this provides us the last proposition of our research.

\section{Data and Methods}

The data required for the case study was obtained from multiple resources as website of the Pakistan Railways, Railways Audited Reports, Speeches of Railways Minister, World Bank report, Railway Gazette and other published resources. The data collected for this case study was retrieved from Railway Year Book 2010 and last five years audited reports.

When there is single organization with unique characteristics, the case study method is most commonly used methodology. 'Case study is an ideal methodology when a comprehensively examination is required (Feagin, 1991). We examined the data for the period from 2005 - 2009, which is considered as the most crucial period for Pakistan Railways.

We examined the strategies followed by the Pakistan Railway. In the context of Railway sector, financial performance is usually gauged from following key indicators:

1. Operating ratios

2. Net surplus

3. Net revenue to capital ratio

These ratios and figures have been given in appendices 1- 8. The World Bank uses these ratios for financial performance evaluation of the Railways sector.

\section{Analysis and Results}

Basically turnaround plan for PRs should focus on market orientation and on the needs of its customers and to achieve this it has to develop and implement different policies regarding freight and passengers services. Following are the brief descriptions of the actions that need to be
Table 1 Financial performance indicator

\begin{tabular}{cccc}
\hline \hline Sr. No & Year & Unit & $2008-2009$ \\
\hline 1 & $\begin{array}{c}\text { Capital at end of year } \\
\text { (Thousands) }\end{array}$ & Rs & $46,646,332$ \\
\hline 2 & Stores Fund (Thousands) & Rs & $16,794,655$ \\
\hline 3 & $\begin{array}{c}\text { Capital layout } \\
\text { (Per Route-Kilometer) }\end{array}$ & Rs & $5,987,207$ \\
\hline 4 & Gross Earning (Thousands) & Rs & $23,158,701$ \\
\hline 5 & Operating Expense & Rs & $28,111,303$ \\
\hline 6 & $\begin{array}{c}\text { Appropriation to Depreciation } \\
\text { Reserve Fund (Thousands) }\end{array}$ & Rs & 416,690 \\
\hline 7 & Net Earnings (Thousands) & Rs & $(1,156,559)$ \\
\hline 8 & Interest Charges (Thousands) & Rs & $5,769,630$ \\
\hline 9 & Gain / (Loss) (Thousands) & Rs & $(22,967,928)$ \\
\hline 10 & Operating ratio & $\%$ & 121 \\
\hline
\end{tabular}

Table 2 Financial indicators

\begin{tabular}{|c|c|c|c|}
\hline Sr. No & Particulars & Unit & $2008-2009$ \\
\hline 1 & Route Kilometers & $\mathrm{Km}$ & 7791 \\
\hline 2 & Track kilometers including sidings & $\mathrm{Km}$ & 11713 \\
\hline 3 & Tonnes carried (Thousand) & Ton & 6937 \\
\hline 4 & Tonne-Kilometers (Thousand) & $\begin{array}{l}\text { Ton/ } \\
\mathrm{Km}\end{array}$ & 5896329 \\
\hline 5 & $\begin{array}{c}\text { Average kilometers a tonne of goods } \\
\text { carried }\end{array}$ & $\mathrm{Km}$ & 849.98 \\
\hline 6 & Coaching Earnings (Thousand) & Rs & 13613244 \\
\hline 7 & Goods Earnings (Thousand) & Rs & 7493634 \\
\hline 8 & $\begin{array}{l}\text { Average rate charged per tonne per } \\
\text { kilometer }\end{array}$ & Paisa & 1.27 \\
\hline 9 & Miscellaneous earnings (Thousand) & Rs & 2051823 \\
\hline 10 & Earning under suspense (Thousand) & Rs & 21043 \\
\hline \multicolumn{4}{|c|}{ Rolling Stock Owned on 30th June } \\
\hline 11 & Locomotives & Nos. & 551 \\
\hline 12 & Coaching vehicle & Nos. & 1763 \\
\hline 13 & Brake-Vans (goods) & Nos. & 425 \\
\hline 14 & $\begin{array}{c}\text { Goods Wagon (in terms of } 4 \\
\text { wheelers) }\end{array}$ & Nos. & 21984 \\
\hline 15 & $\begin{array}{l}\text { Total carrying capacity of goods } \\
\text { Wagons }\end{array}$ & Nos. & 479215 \\
\hline 16 & Persons Employed & Nos. & 85078 \\
\hline
\end{tabular}

taken by PR as a response to its strategic dimensions regarding the turnaround plan described above. On the basis of data collected from different sources the following analyses has been made:

Table 1 shows the financial performance indicator of Pakistan Railways. Although the gross earning has an 
Table 3 Operating revenue

\begin{tabular}{cc}
\hline & (Rs in millions) \\
\hline Year & Total \\
\hline $1950-55$ Average & 315.139 \\
\hline $1955-60$ Average & 420.114 \\
\hline $1960-65$ Average & 514.701 \\
\hline $1965-70$ Average & 645.615 \\
\hline $1975-80$ Average & 959.97 \\
\hline $1980-85$ Average & 2115.474 \\
\hline $1985-90$ Average & 3342.686 \\
\hline $1990-95$ Average & 5094.863 \\
\hline $1995-2000$ Average & 8584.177 \\
\hline $2000-2005$ Average & 9446.065 \\
\hline $2005-2006$ & 14451.235 \\
\hline $2006-2007$ & 18182.079 \\
\hline $2007-2008$ & 19192.485 \\
\hline $2008-2009$ & 19972.828 \\
\hline
\end{tabular}

Table 4 Operating expenses

\begin{tabular}{cc}
\hline Year & Total \\
\hline 1950-55 Average & 209.71 \\
\hline 1955-60 Average & 251.3 \\
\hline 1960-65 Average & 348.69 \\
\hline 1965-70 Average & 479.36 \\
\hline 1970-75 Average & 724.57 \\
\hline $1975-80$ Average & 1701.72 \\
\hline $1980-85$ Average & 3223.65 \\
\hline $1985-90$ Average & 6785.47 \\
\hline $1990-95$ Average & 6937.44 \\
\hline $1995-2000$ Average & 9528.49 \\
\hline $2000-2005$ Average & 12267.5 \\
\hline $2005-2006$ & 17693.6 \\
\hline $2006-2007$ & 20240.6 \\
\hline $2007-2008$ & 21889.8 \\
\hline $2008-2009$ & 28111.3 \\
\hline
\end{tabular}

increasing trend but due to substantial increase in operating cost and borrowing cost (interest cost), the net loss is constantly increase over the years.

Table 2 shows other financial indicators of Pakistan Railways including the routes and tracks length, coaching earnings, goods earnings, other miscellaneous earnings and rolling stock of Pakistan Railways.

Table 3 shows operating revenue of Pakistan Railways
Table 5 Passenger Earnings ratio

\begin{tabular}{cc}
\hline \hline Year & Average Rate per Passenger KMs \\
\hline $1950-55$ Average & 1.75 \\
\hline $1955-60$ Average & 1.97 \\
\hline 1960-65 Average & 2.05 \\
\hline $1965-70$ Average & 2.41 \\
\hline $1970-75$ Average & 2.98 \\
\hline $1975-80$ Average & 4.32 \\
\hline $1980-85$ Average & 7.23 \\
\hline $1985-90$ Average & 9.43 \\
\hline $1990-95$ Average & 22.81 \\
\hline $1995-2000$ Average & 23.47 \\
\hline $2000-2005$ Average & 33.91 \\
\hline $2005-2006$ & 40.07 \\
\hline $2006-2007$ & 40.54 \\
\hline $2007-2008$ & 42.1 \\
\hline $2008-2009$ & 48.96 \\
\hline
\end{tabular}

Table 6 Freight Earnings ratio

\begin{tabular}{cc}
\hline \hline Year & Rate Per Net Ton Per KM \\
\hline $1950-55$ Average & 3.87 \\
\hline $1955-60$ Average & 4.05 \\
\hline $1960-65$ Average & 3.84 \\
\hline $1965-70$ Average & 4.38 \\
\hline $1970-75$ Average & 7.26 \\
\hline $1975-80$ Average & 15.73 \\
\hline $1980-85$ Average & 25.29 \\
\hline $1985-90$ Average & 37.83 \\
\hline $1990-95$ Average & 65.88 \\
\hline $1995-2000$ Average & 95.24 \\
\hline $2000-2005$ Average & 102.98 \\
\hline $2005-2006$ & 99.27 \\
\hline $2006-2007$ & 93.79 \\
\hline $2007-2008$ & 98.92 \\
\hline $2008-2009$ & 127.09 \\
\hline
\end{tabular}

that is passenger earnings and freight earnings. It can be seen from this Table that the freight earning has a downward trend over the mentioned periods.

Table 4 shows the operating expenses of Pakistan Railways having substantial increasing trend over the year causing the increased net losses to PR over the years.

Table 5 shows passenger earnings ratio of the Pakistan Railways which indicates a decreasing trend of number of passengers since the year 1980 . 
Table 7 Percentage of Expenditure to Gross Eevenue

\begin{tabular}{cc}
\hline Year & Percentage \\
\hline $1950-55$ Average & 66.55 \\
\hline $1955-60$ Average & 59.82 \\
\hline $1960-65$ Average & 67.75 \\
\hline $1965-70$ Average & 74.25 \\
\hline $1970-75$ Average & 75.48 \\
\hline $1975-80$ Average & 80.44 \\
\hline $1980-85$ Average & 96.44 \\
\hline $1985-90$ Average & 133.18 \\
\hline $1990-95$ Average & 80.82 \\
\hline $1995-2000$ Average & 100.87 \\
\hline $2000-2005$ Average & 84.89 \\
\hline $2005-2006$ & 97.31 \\
\hline $2006-2007$ & 105.46 \\
\hline $2007-2008$ & 109.6 \\
\hline $2008-2009$ & 121.39 \\
\hline
\end{tabular}

Table 8 Persons employed by Pakistan Railways

\begin{tabular}{ccc}
\hline Year & No. of Employees & $\begin{array}{c}\text { Cost of Employees In } \\
\text { Thousands }\end{array}$ \\
\hline 1950-55 Average & 100734 & 117.686 \\
\hline 1955-60 Average & 110972 & 131.984 \\
\hline 1960-65 Average & 125487 & 178.431 \\
\hline $1965-70$ Average & 134747 & 231.885 \\
\hline $1970-75$ Average & 133748 & 403.943 \\
\hline $1975-80$ Average & 137730 & 640.887 \\
\hline $1980-85$ Average & 127683 & 1126.395 \\
\hline $1985-90$ Average & 131228 & 1990.039 \\
\hline $1990-95$ Average & 120948 & 3414.981 \\
\hline $1995-2000$ Average & 97917 & 4452.961 \\
\hline $2000-2005$ Average & 87988 & 5238.07 \\
\hline $2005-2006$ & 86096 & 7584.778 \\
\hline $2006-2007$ & 86564 & 8597.244 \\
\hline $2007-2008$ & 86669 & 9414.211 \\
\hline $2008-2009$ & 85078 & 10872.556 \\
\hline
\end{tabular}

Table 6 shows the freight earnings ratio of the Pakistan Railways which depicts the ups and downs of the freight earnings of the PR over the year.

Table 7 shows the percentage of expenditure to gross revenue. This also signifies the excess of expenditure over the revenues for the mentioned periods.

Table 8 shows the number of employees and the cost of employment. It indicates that since the year 2000, the cost of employment is increasing substantially but the Pakistan Railways has not considered cost cutting approach.

On the basis of analysis made from the appendices, it is recommended to follow the 3R's Strategy as mentioned below:

\subsection{Retrenchment (overheads reduction activities)}

This is seen as the principal strategy for PR and consist of several sub- strategies that is, eliminating non value adding activities, quitting from the areas and markets where PR's performance is poor, reducing scale of operations and selling assets that become unoccupied, out sourcing activities externally and downsizing. Here the PR should mainly concentrate on cost saving and cutting.

As result of PR's review of its different activities, it has been found that parcel service business, wagon investment schemes and siding liberalization scheme are entirely non value adding in nature and great deal of recourses are tied up with theses services so PR should lease out the parcel services and should involve private investment in the latter said services to free up the tied up resources for other more value adding activities.

\subsection{Repositioning (revenue boosting activities)}

This strategy mainly focused on revenue generation in contrast to the first strategy, Retrenchment (overheads reduction), and consists of various sub-strategies that is growth orientation, product novelty, product differentiation etc. and the ways in which these were adopted are outlined hereunder.

As discussed earlier the main focus of PR should be upon customer requirement and in case of Railway, there are two main types of customers, goods freight and passenger services, and they contribute two third and one third of the total revenue receptively and it is evident from the table that these areas has shown a great deal of growth.

As the number of transportation alternatives has increased and the demand for innovative transportation and components grows, The PR should successfully identify and launch new products that will become one of the key factors for the achievement of repositioning activities. There are two dimensions of such type of activity, the product development process itself and the higher-level skill set of maintaining the necessary level of innovation to support long-term success. The former is an execution capability and the latter is a strategic mindset supported by process.

Differentiation means a product that has different and radically improved attributes in terms of quality and price from competitor's product. To attract the customers, the PR should introduce e-ticketing through World Wide Web, which have become very popular all over the world. 
Moreover, it should introduce passenger coaches with new design that should have significantly higher capacity than former coaches.

\subsection{Reorganization}

This is the third and the last one of the turnaround strategy and is composed of all strategies that are supporting the above two principal strategies for turnaround that is retrenchment and repositioning and it consists of many sub-strategies that is changes in strategic planning structure, delegation of authority, human resource management, and organizational culture.

The PR should adopt improved accounting and management information systems that would help PR to get better financial, operating and management information needed for the most efficient and effective use and to cope with current market needs. This would also help PR for better planning, controlling, organizing and decision making both short term and long term.

Delegation of authority or decentralization and localized control are progressively more recognized as a vital constituent of growing organization because they provide bases in which decision making process can be made better and high quality service can be provided to the customers. Decentralization is helpful in restructuring the organization and is necessary to achieve certain short term goals of the organization. PR can achieve this by creating more zonal centers where authorities should be transferred especially regarding the customer services. Through decentralization zonal officers would be able not only to respond quickly and swiftly to customers' queries and complaints but also many other relevant issues can be taken care of by the same personnel that need weeks to consider.

In the past, PR had a history of high number of accidents. It should take several measures to minimize all such incidents. PR should introduce crew friendly driver's cabins and brake vans should be designed. It should make available many sport facilities to its employees that have even won many sports programs both nationally and internationally. These all steps would result in more effective use of manpower and improvement in staff productivity and would increase employee motivation. The PR should make radical changes to its culture through theoretical change. Currently, most of the business decisions are of political nature. PR now should realize and should adopt a more customer oriented approach focusing on matters like customers' needs and competitive services.

In the above discussion that we made above it is evident that Pakistan Railways can be benefited a lot from its turnaround strategies of retrenchment, repositioning and reor- ganization but there are some macro-economic factors that may also contribute towards the revival of the PR.

\subsection{Environmental factors}

This mainly includes the fact that Pakistan's economy has not raised and it has not allowed favourable business and trade activities. As a result of low business activities PR has not gained high revenue due to lower demand for its services that is already discussed above. A business life cycle is composed of series of up (economic growth) and downs (economic downfall) measures. During economic growth, the organization grows and this leads to more jobs opportunities and increased revenues.

\section{Conclusion}

From the above discussion it can be concluded that there are various internal (managerial) and external environmental (economic) factor that have impact on the Pakistan Railway's decline. Retrenchment strategy will help in reduction of overheads and it concentrates on dynamic pricing and customer focused approach together with repositioning strategy to enhance the revenue generation of the PR specially the freight revenue. Reorganization strategies like human resource management policies and successful results of decentralization of authorities and responsibilities may also help win the PR's growth. Summing up the whole discussion the PR's turnaround may be achieved not only through implementation of managerial strategies (retrenchment, repositioning and reorganization) but also through change in favorable environmental factors also.

\section{References}

1. Arogyaswamy, K., Barker, V. L. and Yasai-Ardekani, M. (1995). "Firm Turnarounds:an Integrative Two Stage Model," Journal of Management Studies, pp. 493-525.

2. Audit General of Pakistan. (2005-6, 2006-7, 2007-8, 20089). Audit Reports.

3. Boyne, G. and Meier, K. (2005). "Good Luck and Good Management and Organisational Turnaround in the Public Sector," CLRGR Papers in Public Policy and Service Improvement, 14.

4. Boyne, G. A. (2010). A '3Rs' Strategy for Public Service Turnaround; Retrenchment, Repositioning and Reorganization.

5. Boyne, G. (2006). "Strategies for Public Service Turnaround : Lessons from the Private Sector?," Administration and Society, pp. 365-88.

6. Bruton, G., Athlstrom, D. and Wan, J. (2003). "Turnaround in East Asian Firms: Evidence from Thnic Overseas Chinese Communities," Strategic Management Journal, pp. 519- 
40.

7. Dawley, D., Hoffman, J. and Lamont, B. (2002). "Choice Situation, Refocusing and Post Bankruptcy Financial performance," Journal of Mangement, pp. 695-717.

8. Glynn, J. and Murphy, M. (1996). "Public Management, Failing Accountabilities and Failing Financial Performance Review," International Journal of Public Sectore Management, Vol. 9, No. 5, pp. 13-27.

9. Hitt, M., Bierman, L., Shimizu, K. and Kochhar, R. (2001). "Direct and Moderating Effect of Human Capital on Strategy and Financial Performance in Professional Services: A Resource Based Respectives," Academy of Management Journal, Vol. 44, pp. 13-28.

10. Hoffman, R. (1989). "Strategies for Corporate Turnaround: What Do We Know About Them?," Journal of General Management, Vol. 14, pp. 46-66.

11. Feagin, A. O. (n.d.). A case for case study. Chapel Hill, NC: University of North Carolina Press.

12. Morrow, J. J. and Busenitz, L. (2004). "The effect of cost and Asset Retrenchment on Firm Financial Performance:the
Overlooked Role of a Firm's Competitive Environment," Journal of Management, pp. 189-208.

13. Raghuram, G. (2007). "Turnaround of Indian Railways: A critical appraisal of strategies and processes," Indian Institute of Management Working Papers no 2007-02-03, Indian Institute of Management, Ahmedabad.

14. Railway Gazette. http://www.Railwaygazette.com/news/single-view/view/crisis-at-Pakistan- Railways.html.

15. Robbins, K. and Pearce, J. (1992). "Turnaround: Retrenchment and Recovery," Strategic Management Journal, Vol. 13, pp. 287-309.

16. Schendel, D., Patton, G. R. and Riggs, J. (1976). "Corporate Turnaround Strategies: A Study of Profit, Decline and Recovery," Journal of General Management, Vol. 33, pp. 312.

17. Skaggs, B. and Youndt, M. (2004). "Strategic Positioning, Human Capital and Financial Performance In Service Organisations: A Customer Interaction Approach," Strategic Management Journal, Vol. 25, pp. 85-99.

18. World Bank Report http://go.worldbank.org/7CYYM39VG0. 